\title{
Even in death, unsilenced: Afro-Brazilian art as identity fortification instruments among medicine students
}

\author{
Pra nem morta ser calada: arte afro-brasileira como fortalecimento \\ identitário entre estudantes de medicina
}

Marina Moreira ${ }^{1}$

DOI: $10.1590 / 0103-1104202112915$

\begin{abstract}
Plagued by violence and racial discrimination, the black population experiences the worst levels of vulnerability as to violence and health indicators. The National Policy for Comprehensive Health of the Black Population recognizes racism as central to the production of inequities, but is not able to overcome the influence of eugenic theories in the health field. Even though a significant part of health professionals, black women continue to face the inexpressive production of knowledge about their own health. Questioning this excluding reality, this experience report aims at exploring the use of the stencil technique as an instrument of resistance for identity construction and demarcation of territory by medical students affected by marginalization processes. Using materials common to the daily lives of health professionals, it was possible to portray different images that are relevant to the struggle of minorities and the personal identity of the participants. Based on the black culture, this workshop served as a center for teaching and social mobilization, enabling for the creation of both resistance and self-affirmation tools.
\end{abstract}

KEYWORDS Social construction of ethnic identity. Health of ethnic minorities. Art.

RESUMO Assolada pela violência e pela discriminação racial, a população negra integra os piores índices de vulnerabilidade à violência e indicadores de saúde. A Política Nacional de Saúde Integral da População Negra reconhece o racismo enquanto central na produção de iniquidades, mas não é capaz de superar a influência das teorias eugênicas no campo de saúde. Embora sejam parte expressiva dos profissionais da saúde, mulheres negras continuam encarando a inexpressiva produção de conhecimento sobre sua própria saúde. Questionando essa realidade excludente, este relato de experiência teve o objetivo de explorar a utilização da técnica de estêncil como instrumento de resistência para construção identitária e demarcação de território por alunas e alunos de medicina atingidos por processos de marginalização. Utilizando-se de materiais comuns ao cotidiano de profissionais de saúde, foi possível retratar diferentes imagens relevantes para a luta das minorias e para a identidade pessoal dos participantes. A partir da cultura negra, essa oficina atuou como centro de ensino e de mobilização social, possibilitando a criação de instrumentos de resistência e autoafirmação.

PALAVRAS-CHAVE Construção social da identidade étnica. Saúde das minorias étnicas. Arte.

\footnotetext{
1 Universidade de Brasília (UnB) - Brasília (DF),

Brasil.

marinamoreira32@gmail.

com
} 


\section{Introduction}

When it comes to vulnerability to violence, Brazilian 'Atlas of Violence 2020' points to a territory divided into two completely different countries' ${ }^{\mathbf{1}}$. Racial inequality has deepened over the last decade; and between 2008 and 2018, homicide rates increased by $11.5 \%$ for blacks, while they decreased by $12.9 \%$ for non-blacks. In $2018,75.7 \%$ of victims of lethal violence were black. According to the report, in the land of Zumbi dos Palmares, the state of Alagoas, the homicide rate of black people is 17.2 times higher than that of non-blacks, making it the state with the greatest differences in victimization between blacks and non-blacks 1 .

Violence is also a matter of public health, and every black body fallen on the ground directly and indirectly impacts the physical and mental health of the community ${ }^{2}$. Fear affects the way black people behave in the world, which makes racism a psychological burden ${ }^{\mathbf{2} 3}$. As demonstrated by numerous researches, racism exposes black men and women to degrading and humiliating situations on a daily basis, making them especially susceptible to developing disorders such as tachycardia, hypertension, gastric ulcer, anxiety, panic attacks, depression, difficulty opening up, violent and seemingly unprovoked rage attacks, identity compromise, and self-concept distortion ${ }^{3}$.

Contrary to the widely publicized common sense of tolerance and acceptability of black people in Brazil, based on the myth of racial democracy, racial discrimination has direct effects on the health of the black population ${ }^{4}$, thus becoming a public health problem. The National Policy for Comprehensive Health of the Black Population, passed in 2006 by the National Health Council, and enforced in 2009 by the Ministry of Health, recognized racism as a central factor to the production of health inequities, highlighting its institutional form, within the Unified System of Health itself ${ }^{5}$. Although important in the political sphere, this acknowledgement was not able to overcome the racist influence of eugenic theories in the health field 6 .

Although often denied in contemporary studies, the central role that Brazilian medicine played in strengthening discriminatory and racist behavior by embracing international eugenic ideals must not be forgotten ${ }^{7}$. The dissemination of racist content was widely carried out by Brazilian physicians, by means of acts such as the creation of the São Paulo Eugenic Society, in 1918, he Brazilian Conference on Eugenics, the foundation of São Paulo League for Mental Hygiene and the publication of the periodical Eugenics Bulletin 7 . According the production of those influential nineteenth-century physicians, who at the time had scientific status, black or mixed race persons were determined from birth to be more prone to madness and diseases for biological reasons, not social ${ }^{8}$ ones. By disqualifying the actual causes of illness and suffering among black and mixed race people, associating them with psychical and social degeneration, the influence of the racist history of Brazilian medicine went beyond offices and hospitals and began influencing public and social policies ${ }^{7}$.

The historical effects of such thinking are still manifested in various areas of the knowledge production, helping perpetuate the obliviousness of most Brazilian scientific production concerning the suffering of ethnic minorities ${ }^{2}$. A clear example is the case of black women, who, despite being a significant part of the health professionals and holding vast historical and cultural experience in the art of care, continue to face the inexpressive production of scientific knowledge about their own health, which remains a vague, poorly discussed subject in both undergraduate and graduate curricula, ignored by most researchers, students, professors and health professionals in Brazil6.

Instigated to question this exclusionary reality that permeates both the academic 
and the clinic ambiance, and on the purpose of bringing different perspectives for the educational future of health professionals, two undergraduate medical students in a federal Brazilian university decided to organize a stencil workshop, in order to paint the white walls of the Academic Student Center with bright colors and black themes, retaking, through the art, the space that was institutionally denied to them.

The workshop, held on September 25, 2018, was open to the academic community during the Academic Week at the College of Health, and received the title 'Even in death, unsilenced!', inspired by a song by the rapper Djonga ${ }^{9}$, from his album 'Heresia' (Heresy), which carries the verse "dropping lines, so that even in death I'll be unsilenced". This case study is aimed at exploring the use of black art during the workshop as an instrument for discussing strategies of identity construction and territorial demarcation by students affected by marginalization processes.

\section{Materials and methods}

Stencil painting is a popular graffiti technique that consists of applying paint, either using aerosol or other tools, over a mold usually made of paper or acetate. The molds used in the workshop were constructed by the participants themselves, through the recycling of $\mathrm{x}$-ray plates that were cut with scalpels.

Initially, four images relevant to the personal identity of the participants were chosen: the face of Marielle Franco (four layers of paint, four molds); the Black Panther Party symbol (four layers of paint, four molds); the profile of a black woman's face with the African continent as background (unique layer and mold); and a graphic symbol accompanied by a pun questioning hetero-normativity (unique layer and mold).

In order to achieve the desired stencil effect, the images were edited using computer software (figure 1), assigning them layers of color that simulate natural lighting. The number of layers varied according to the complexity of the images: only one for the simplest, and up to four for the more complex ones, such as human faces (figure 2).

Figure 1. Image of Marielle Franco's face after digital editing. The final stencil will have four overlapping color layers: black, gray, white and black

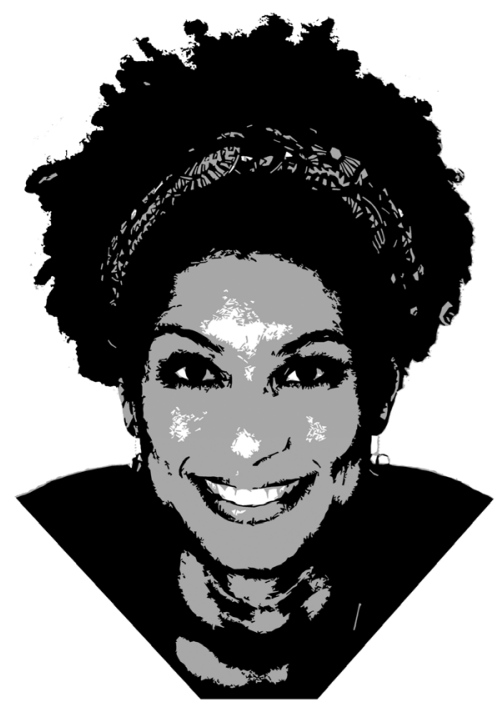


Figure 2. Photo of the four plates corresponding to each color layer for the stencil of Marielle Franco's face

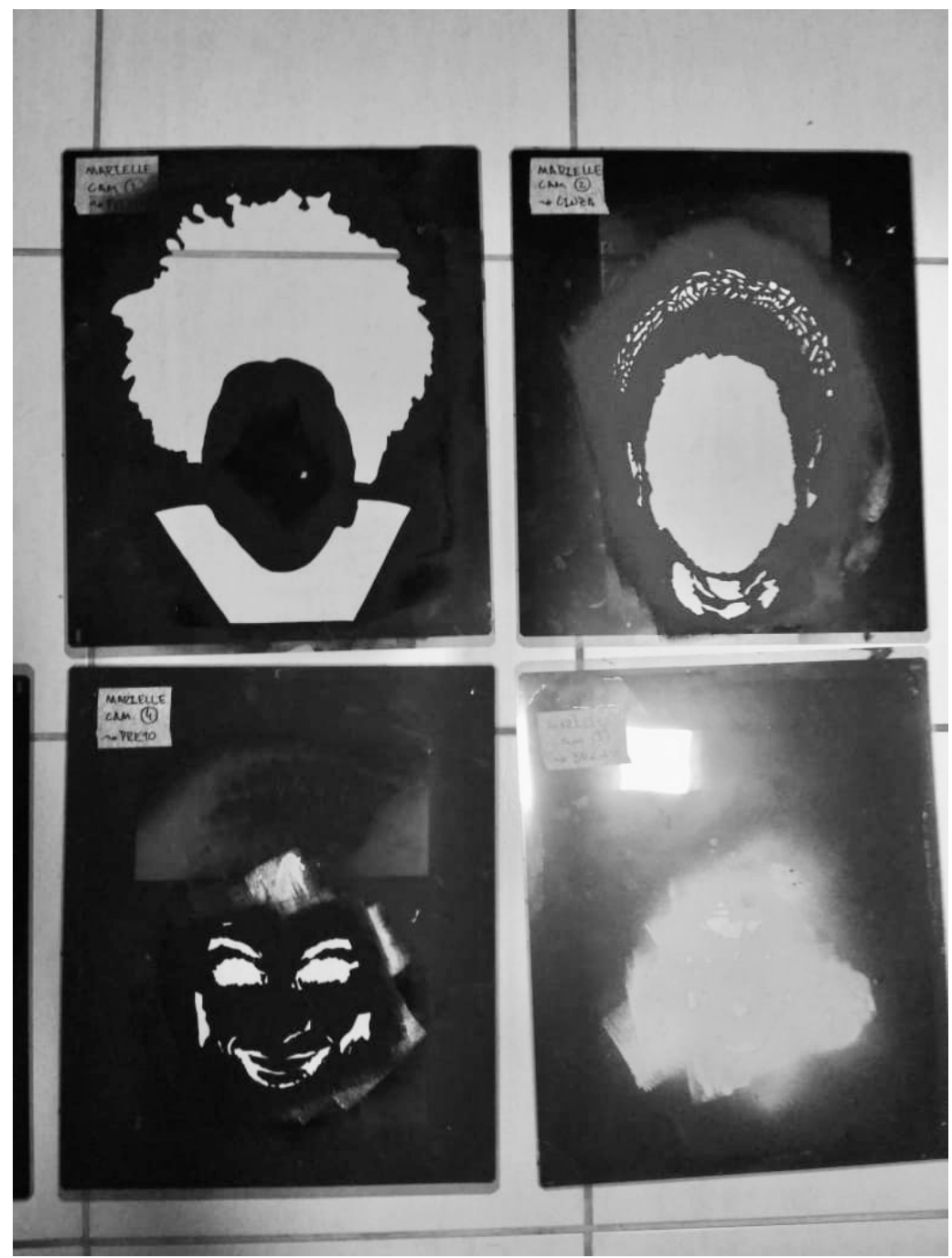

The resulting layers were then printed on A3 size sheets of white paper, which were used as temporary templates to transfer the images to their final molds. In this purpose, they were superimposed on the x-ray plates, which were then cut with the aid of scalpels, following the contours and demarcations of the printed sheets. At this stage, the most timeconsuming and delicate of the process, tables with glass tops were used, in order to increase control over the cutting surface and pressure placed on the sheet.

Once cut, the x-ray plates were used as molds to superpose the paint layere that, combined, gave form to the images chosen to occupy the walls of the Academic Center (figures 3, 4 and 5). During the workshop, black culture music was performed, playing genres such as samba, rap (an acronym for rhythm and poetry), funk and hip-hop. 
Figure 3. Photo of the final artwork for the Black Panthers Party symbol, applied to the wall, with the students' signatures

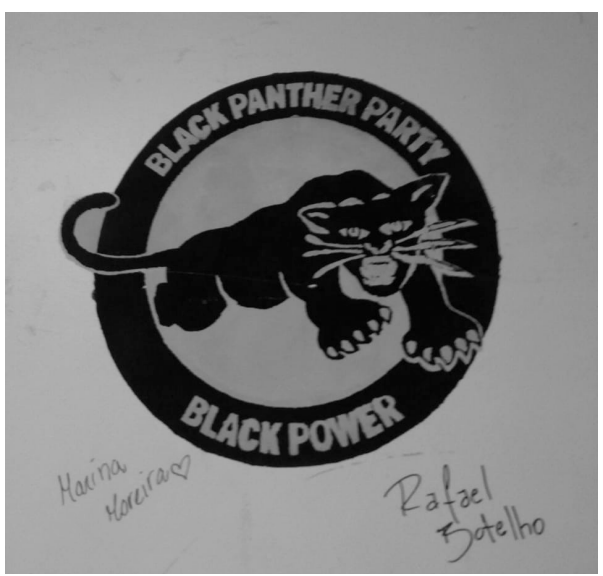

Figure 4. Photo of the final stenciled artwork of Marielle Franco's face applied to the wall, after the student's signature was vandalized

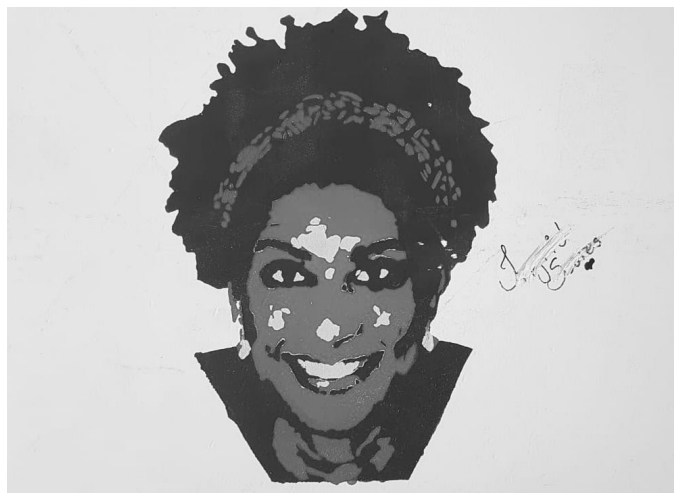

Figure 5. Photo of the final artwork for the graphic symbol, applied to the wall, surrounded by student's signatures. All artworks were later on depredated.

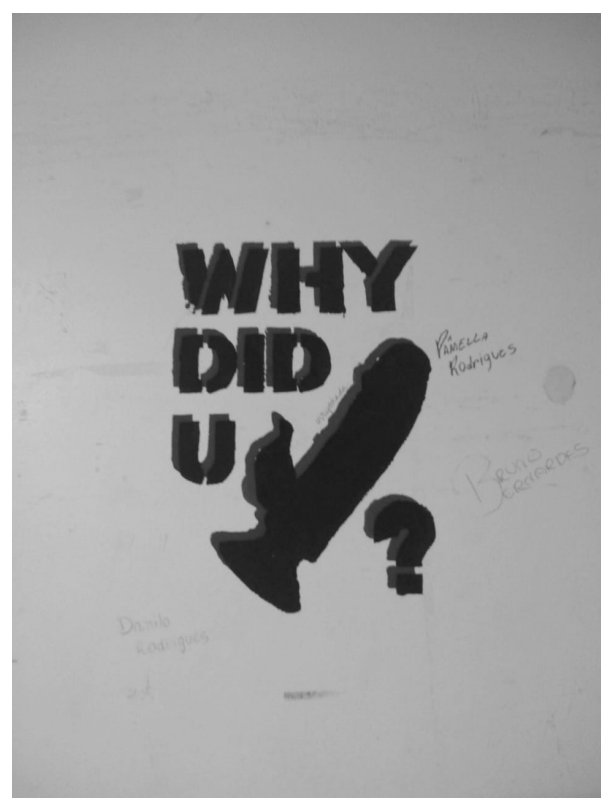




\section{Art as resistance}

The choice of materials - recycled x-ray plates (courtesy of the University Hospital) and scalpels, used in the daily lives of healthcare professionals - was not accidental. The goal was to reinvent and give them new meanings, demonstrating that they can be used to make urban art and to portray black culture, as a form of resistance. Culture, here, is used in the sense of keeping traditions, as adopted by Stuart Hall: a means to help struggles to survive in the historical black people's struggle in their diaspora, using the black aesthetics, their own cultural repertoires and counter-narratives that black people fight to express ${ }^{10}$. Black urban culture has several manifestations that use public spaces as meeting spaces, such as graffiti, dances and various musical styles. Consequently, in addition to entertainment and art, music, one of the main manifestations of the black culture, is a means to identity the construction of identity and resistance"1, which explains its use during the process of designing and creating the stencils.

Therefore, youth organizations structures around ethno-artistic movements (such as funk, hip-hop and rap) are also educational environments, as those who participate do so in ambiances that provide political education, with critical attitude and a more creative interpretation of the reality ${ }^{\mathbf{2}}$. They are spaces where the voice of those who are left aside can be heard, as well as reflections on what excludes the less favored classes, particularly the rap, the most raw report of violence and exclusion, but also of resistance and cultural richness ${ }^{11}$. Gustavo Pereira Marques, popularly known by his stage name Djonga, is one of the biggest names in Brazilian" rap .Born in the community of Índio, in Belo Horizonte, he attended the History College at the Federal University of Ouro Preto, and currently produces songs that address the social place of black people, delving into themes such as racism, police brutality, black pride, traditions and ancestry, clearly commited to the construction of black identity and resistance ${ }^{11}$. Therefore, the choice of his verse to name the workshop was intended to highlight the intend of denunciation and the hope it shares with his art.

Political education as a project is no news for the black movement. Taking responsibility for the education of its people has been a constant in the history of African expressions in Brazil; and as already evidenced in several projects and practices of this movement, culture and education are intimately related ${ }^{\mathbf{1 2}}$. Unfortunately, black students admitted through affirmative action programs (such as the quota system) suffer double discrimination in the academic space: for being quota students, and for being black. And the mere access to higher education has not been able to guarantee a stronger black identity ${ }^{13}$. Even so, it is important for these students to feel part of this new space, so that they can feel identified with other university students and with the university culture ${ }^{13}$. Accordingly, federal public universities, which have been experiencing changes in the previous hegemonically white profile of academics since the introduction of affirmative action policies ${ }^{\mathbf{1 3}}$, carry the responsibility of promoting events for cultural, physical and emotional re- signification, if they really intend to build an integrated education that dialogues with social issues. Just providing access is not enough.

The inconvenience caused by the artworks created during the workshop was enough to raise questions and even depredations by other students that attend the Academic Center. Thus, by taking part of events such as this workshop, students who feel marginalized act as political agents, and their organization for the valorization of Afro-Latin culture and 'making black art' functions not only as educational centers, but also for social mobilization, with black artistic manifestations as its epicenter. 
Educational measures instrumentalized by art are productive and intellectual tools for both artistic and emotional personal and community expressions. By working with black culture and visual themes, one can enable the creation of instruments of resistance and self-assertion in each individual.

Hence, black self-assertion gains the sense of exalting the phenotypic physical (hair, nose, mouth and skin) and cultural (clothing, music and art) aesthetic characteristics, enabling the revaluation of these historically undervalued traits ${ }^{13}$. Living in a world of black skins, white masks ${ }^{14}$, especially in extremely elitized environments, such as the academic world, amplifies the effects of centuries of public and private devaluation on black people's self-esteem ${ }^{\mathbf{1 3}}$. Therefore, it is also necessary to educate in ways of dismantling the feelings of inferiority over black physical and cultural traits, in both an academic and social perspectives.

Furthermore, health vulnerabilities are products of the social hierarchy created by structuring factors in society, such as racism and sexism ${ }^{6}$. In Brazil, these vulnerabilities were accentuated by centuries of eugenic medical practices, such as involuntary sterilization ${ }^{7}$. The inequities are described in several studies, and black women are less likely to undergo complete gynecological and prenatal consultations and to receive information about childbirth and its signs, healthy eating during pregnancy and breastfeeding and its importance 4 . On the other hand, they are more likely to have their first child under the age of 16 , to become pregnant unintentionally, to not receive medical care during pregnancy and to not be properly examined ${ }^{4}$. More recent data indicate that, during the Covid-19 global pandemic, populations belonging to minority ethnic groups were disproportionately affected ${ }^{15}$ and, in Brazil, maternal mortality of black women as a result of this infection is almost twice as high as of white women ${ }^{16}$. Thus, the choice of the figure of the black woman over Africa, in addition to valuing their phenotypic traits, made possible the discussion of the invisibility of inequities that affect black women. It should be remembered that the prejudiced and stereotyped views of a portion of health professionals place a wedge between them and patients that belong to marginalized racial groups, undermining interpersonal trust relationships and the ones between individuals and the health system ${ }^{6}$. The lack of representation and discussion of these inequities, in both academic and clinical ambiances, contribute for the continuation of professionals' inability to perceive health inequalities, denying them and collaborating for their maintenance and expansion ${ }^{4}$.

Institutional racism, a concept coined by members of the Black Panther Party, is an intrinsic process of colonialism that describes the disguised - but nevertheless perverse and destructive - face that operates from the respected and established forces in the society, preventing public services, such as health, of being offered to their full extent to people because of their color, culture or ethnic origin ${ }^{17}$. Probably the most ignored dimension of racism, the institutional racism is displaced from the interpersonal and individually practiced dimension to the structural dimension, drawing on the actions and behaviors of public and private institutions that produce and reproduce racial hierarchies, permeating the entire system of health in all its levels and spheres ${ }^{6}$. One of the main references in the anti-racist struggle, the symbol of the Black Panthers Party was chosen by the workshop participants in recognition of the extensive legacy of cultural and academic production, representation, acts, legislation, history and hope that the group represents for rising black people throughout the world.

Considering the stencil as a tool of resistance, by painting the walls of the Academic Center with the face of Marielle Franco, 
the students demarcated ideological territory. Marielle Franco was a black, bisexual woman, resident at the Maré community, and one of the most active councilors in Rio de Janeiro City Council. On March 14, 2018, she was shot four times in the head during an attack on the vehicle in which she and her security guard were. Marielle had just participated in a debate titled 'Black Youth Moving Structures' at Casa das Pretas, with an audience full of black university students ${ }^{18}$. Marielle Franco had also been a student in a communitary university preparation school, graduated from a public university and had a master degree in public security. She was known for giving voice to the excluded in the academic world and in the government ${ }^{19}$. Her murder has often been considered an attempt to silence one of the leading political voices of the black community. Another bullet that tries to silence the voice of resistance.

Regrettably, Brazil is the world leader in homicides of transsexuals and transgender individuals, with more than three times the number of homicides of Mexico, the second place ${ }^{20}$. In 2019, victims of murders of transvestites and transsexuals in Brazil were composed by $82 \%$ of black people and by $97.7 \%$ of women ${ }^{21}$. Regarding access to health, the population of lesbians, gays, bisexuals, and transgender individuals are in a particularly fragile spot, being often victimized by professionals themselves ${ }^{\mathbf{2 2}}$. Fear of revealing their gender identity or sexual orientation, stigma and discrimination (especially related to sexually transmitted infections), medical ignorance regarding various health demands, non-use of social name, moral and religious judgment, disapproval of speech, gestures and looks, ignorance of the National Comprehensive Health Policy for Lesbians, Gays, Bisexuals, Transvestites and Transgenders and transference to patients of the blame for poor quality treatment are just some of the problems observed in medical education and professional practice ${ }^{22}$. Consequently, it is urgent to broaden the discussions that question the mandatory heteronormativity and cisgenderism in health education, and that special attention be paid to reports and observations of academic experience of students that belong to groups excluded by this standard. The choice of the graphic symbol questioning cis-heteronormativity was a humorous way found by the workshop participants to challenge this violent reality.

\section{Final considerations}

They are so many, the deaths that black people experience. Racism, fear and silence as death in life. Indifference, defamation and epistemicide (erasure of constructed knowledge) ${ }^{\mathbf{2 3}}$ as symbolic and spiritual death. Neglect, starvation and murder as physical death. Resistance, a word that permeated every activity carried out in the workshop, has a meaning that encompasses the cultural value, political struggle and self-esteem of each student that enters an elitized, white, cis-heteronormative, LGBTphobic and racist space, such as that of higher education courses in the field of health, especially medicine.

Today, at the College of Health, when headed to the Academic Center for Medical Students, it is possible to see not only the face of Marielle Franco, the face of a black woman over the African continent, the symbol of the Black Panther Party and a graphic symbol questioning cis-heteronormativity, but also the names of the students who signed the works, surrounding them. The cold white walls were overtaken by the names of black and white people, of diverse gender identities and sexual orientations, such as lesbians, gays, bisexuals and transgender. A physical space for selfassertion was created, which remains for all students to admire and take part of.

By signing their names with pride, the students demarcated a territory that was not only previously denied, but actively produced and, 
even indirectly, continues to produce ignorance that is used to keep these individuals at the margins of the society. In this workshop, the stencil was used as a form of expression of urban art, overlayed with resistance. Black students, quota students, gays, lesbians, bisexuals and transgender people exist, resist and occupy the public university, with their bodies, their voices, their skin, their aesthetics and their knowledge. From Martin Luther King to Marielle Franco, bullets will not silence our voices.

\section{Collaborator}

Moreira M (0000-0002-3141-1932)* is responsible for the writing of the manuscript.

\section{References}

1. Instituto de Pesquisa Econômica Aplicada. Atlas da Violência 2020. 2020. [acesso em 2020 ago 29]. Disponível em: https://www.ipea.gov.br/atlasviolencia/ download/24/atlas-da-violencia-2020.

2. Gouveia DM, Loyola ZVM. Saúde Mental e Racismo Contra Negros: Produção Bibliográfica Brasileira dos Últimos Quinze Anos. Psicol Ciência e Profissão. 2018 [acesso em 2020 jul 29]; 38(3):450-64. Disponível em: https://doi.org/10.1590/1982-37030003262017.

3. Silva ML. Racismo e os Efeitos na Saúde Mental. In: Batista LE, Kalckmann S, organizadores. Seminário saúde da população negra Estado de São Paulo 2004. São Paulo: Instituto de Saúde; 2005. p. 129-132.

4. Lopes F. Experiências desiguais ao nascer, viver, adoecer e morrer: tópicos em saúde da população negra no Brasil. In: Batista LE, Kalckmann S, organizadores. Seminário saúde da população negra Estado de São Paulo 2004. São Paulo: Instituto de Saúde; 2005. p. 53-101.

5. Brasil. Ministério da Saúde, Secretaria de Gestão Estratégica e Participativa. Política Nacional de Saúde Integral da População Negra: uma política do SUS. 3. ed. Brasília, DF: Editora do Ministério da Saúde;
2017. [acesso em 2020 jul 29]. Disponível em: www. saude.gov.br/bvs.

6. Werneck J. Racismo institucional e saúde da população negra. Saude e Soc. 2016; 25(3):535-49.

7. Verzolla BLP, Mota A. Representações do discurso médico-eugênico sobre a descendência: a eugenia mendelista nas teses doutorais da faculdade de medicina e Cirurgia de São Paulo na década de 1920. Saude e Soc. 2017; 26(3):612-25.

8. Engel MG. As fronteiras da 'anormalidade': psiquiatria e controle social. Hist. Ciênc. Saúde-Manguinhos. 1999 [acesso em 2020 jul 31]; 5(3):547-63. Disponível em: http://www.scielo.br/scielo.php?script=sci arttext\&pid=S0104-59701999000100001\&lng=pt\&t lng=pt.

9. Djonga. Heresia [Youtube]. [2017]. [acesso em 2020 jul 29]. Disponível em: https://music.youtube.com/ playlist?list=OLAK5uy_lKyF7uVNh3nnAy5g2Xs8bknMJCpoC6WHI.

10. Hall S. Da Diáspora: Identidades e Mediações Culturais. Belo Horizonte: Editora UFMG; 2003.
*Orcid (Open Researcher and Contributor ID). 
11. Fernandes G, Azevedo N, Santos S, et al. O rap como ferramenta de resistência: A influência da musicalidade de Djonga para a construção de sentido da luta negra no País. In: Anais do $24^{\circ}$ Congresso de Ciências da Comunicação na Região Sudeste; 2019 Jun 3-5; Vitória. Vitória: UFES; 2019.

12. Gonçalves LAO, Silva PBG. Movimento negro e educação. Rev Bras Educ. 2000; (15):134-58.

13. Marques EPS, Ribeiro MAPS. O fortalecimento da identidade negra na educação superior: entre a negação e o reconhecimento. Interfaces da Educ. 2017; 8(23):53-73.

14. Fanon F. Pele negra, máscaras brancas. Salvador: EDUFBA; 2008.

15. Khunti K, Kumar Singh A, Pareek M, et al. Is ethnicity linked to incidence or outcomes of covid-19? BMJ. 2020 [acesso em 2020 jun 7]; 1-2. Disponível em: https://www.bmj.com/content/369/bmj.m1548.

16. Santos DS, Menezes MO, Andreucci CB, et al. Disproportionate impact of Coronavirus Disease 2019 (COVID-19) among pregnant and postpartum Black Women in Brazil through structural racism lens. Clin Infect Dis. 2020 [acesso em 2020 jul 29]; 72(11):20682069. Disponível em: https://academic.oup.com/cid/ article-abstract/doi/10.1093/cid/ciaa1066/5877027.

17. Carmichael S, Hamilton C. Black power: the politics of liberation in America. Vintage. Nova Iorque: Random House; 1992.
18. Mesquita L. Os últimos momentos de Marielle Franco antes de ser morta com quatro tiros na cabeça. BBC News Brasil. 2018 mar 15. [acesso em 2020 jul 31]. Disponível em: https://www.bbc.com/portuguese/ brasil-43414709.

19. Franco M. UPP - A redução da favela a três letras: uma análise da política de segurança pública do estado do Rio de Janeiro. [dissertação]. Niterói: Universidade Federal Fluminense; 2014.

20. Balzer C, Lagata C, Berredo L. 2,190 murders are only the tip of the iceberg-An introduction to the Trans Murder Monitoring project - TMM annual report 2016. Germany: TvT Publication; 2016. [acesso em 2020 jul 31]. Disponível em: www.tgeu.orgwww. transrespect.org.

21. Benevides BG, Nogueira SNB. Dossiê dos assassinatos e da violência contra travestis e transexuais brasileiras em 2019. São Paulo: Expressão Popular, ANTRA, IBTE; 2020.

22. Negreiros FRN, Ferreira BO, Freitas DN, et al. Saúde de Lésbicas, Gays, Bissexuais, Travestis e Transexuais: da formação médica à atuação profissional. Rev Bras Educ Med. 2019; (43):23-31.

23. Montenegro AMR. Resenha Carneiro S. Escritos de uma vida. São Paulo: Pólen Livros, 2019. Cad da Esc do Legis. 2019; 21(35):163-75.

\footnotetext{
Received on 31/08/2020

Approved on 05/03/2021

Conflict of interests: non-existent

Financial support: non-existent
} 